\title{
Global DNA Methylation Profile
}

National Cancer Institute

\section{Source}

National Cancer Institute. Global DNA Methylation Profile. NCI Thesaurus. Code C129903.

The analysis of all of the methylated nucleotides present in the genome in a biological sample. 